DOI https://doi.org/10.30525/978-9934-26-039-1-44

\title{
ЧАСТИНОМОВНІ МОДЕЛІ АНГЛОМОВНИХ ВІЙСЬКОВИХ ТЕРМІНІВ
}

\author{
Лемешко О. О. \\ аспірант кафедри германських мов і перекладознавства \\ Дрогобицького державного педагогічного університету \\ імені Івана Франка \\ Сліпецька В. Д. \\ кандидат філологічних наук, \\ доиент кафедри германських мов і перекладознавства \\ Дрогобииького державного педагогічного університету \\ імені Івана Франка \\ м. Дрогобич, Львівська область, Украӥна
}

Постановка проблеми. Об'єкт нашого дослідження - англомовні військові терміни. Предмет дослідження - частиномовні моделі англомовних військових термінів, що використовуються в збройних силах Сполучених Штатів Америки, Великої Британії та Канади. Загальна кількість одиниць у нашій вибірці - 5000 англомовних військових термінів. Ці терміни були відібрані шляхом суцільної вибірки 3 лексико-графічних джерел таких, як DOD Dictionary Of Military And Associated Terms, NATO Glossary Of Terms And Definitions (English And French), The Official NATO Terminology Database, Військовий Стандарт 01.030.001-2020 (Видання 1), Manual Of Abbreviations Department Of National Defence And The Canadian Armed Forces, MOD Acronyms And Abbreviations.

Мета. Схарактеризувати частиномовні моделі англомовних військових термінів. Поставлена мета вимагає виконання таких завдань: описати частиномовні моделі військових термінів; виокремити продуктивні частиномовні моделі термінів в сучасних військових терміносистемах Сполучених Штатів Америки, Великої Британії та Канади; висвітлити взаємозв'язок частиномовних моделей термінів зі структурними характеристиками (лексичною довжиною). У нашому дослідженні використано такі методи - метод лінгвістичного опису, метод компонентного аналізу та елементи кількісного аналізу.

Виклад основного матеріалу. Основним джерелом інформації для цього дослідження $є$ вибірка військових термінів, які були відібрані 
шляхом суцільної вибірки 3 лексико-графічних джерел військового спрямування. Загальна сума відібраних термінів становить 5000 одиниць. За своїм складом проаналізовані терміни та їх частиномовні моделі представлені майже всіма самостійними частинами мови та деякими службовими. У статті присвяченій аналітичні номінації термінів Разбєгіна Н.В. відзначає, що: «навіть попри актуальність та активні дослідження неоднослівних термінів, у науковому дискурсі відсутня одна, узгоджена дефініція для них.» [3, с. 346]. 3 метою уникнення неточностей, для зручності у цьому дослідженні замість поняття неоднослівний термін буде використано поняття - багатокомпонентний термін [4]. У працях присвячених структурі термінів науковці пояснюють домінацію багатокомпонентних термінів наступними аргументами: «Перевага надається термінам-словосполученням, оскільки вони здатні найбільш повно відобразити необхідні специфічні риси поняття, яке називається аналітичними термінами» [2, с. 104]. Також вищевказані показники підтверджують твердження вченого С. Гриньова, який зауважує, що 60-95\% термінів в сучасних європейських мовах - це багатокомпонентні одиниці [1, с. 137].

Після розподілу та аналізу термінів за кількістю компонентів, на основі підготовленої для цього дослідження вибірки було здійснено аналіз та визначення найпродуктивніших частиномовних моделей у термінах 3 різною кількістю компонентів. В ході дослідження було виявлено, що найбільшою категорією термінів $є$ двокомпонентні терміни, загальна кількість яких становить 45,54\% від загальної кількості усіх термінів у цьому дослідженні. У цій категорії найбільш розповсюдженими частиномовними моделями $\epsilon$ іменник+іменник $(N+N-51,56 \%$, наприклад: air assault; demolition kit;) та прикметник+іменник $(A+N-42,60 \%$, наприклад: dead zone; key terrain). В. Д. Сліпецька у своїй дисертації «Англомовна термінологія штучного інтелекту в контексті інших терміносистем (досвід лінгвостатистичного аналізу)» відзначає що: «Домінування утворень типу $\boldsymbol{N} \boldsymbol{N}$ серед інтрагалузевих термінів пояснюється тенденцією до лаконічності та спрощення мовних форм i широким діапазоном семантичних відношень, що їх здатна передавати ця конструкція. Використання моделі $N \boldsymbol{N}$, безумовно, відповідає потребам мовця, тут автора наукового твору» [5, с. 11]. Другою за кількістю групою термінів у дослідженні є трикомпонентні терміни, які складають $26,70 \%$ від загальної кількості всіх термінів використаних у дослідженні. За підрахунками було визначено, що двома домінуючими частино мовними моделями серед трьохкомпонентних термінів $є$ іменник + іменник + 
іменник $(N+N+N-35,81 \%$, наприклад: air target chart) та прикметни + іменник + іменник $(A+N+N-31,01 \%$, наприклад:critical target elemen). Категорією, котра має найбільшу варіативність частиномовних моделей $\epsilon$ чотирикомпонентні терміни. Ця категорія продовжує демонструвати схожу тенденцію за складом частиномовних моделей. 352 варіантів частиномовних моделей найбільш розповсюдженими серед чотирьохкомпонентних військових термінів $\epsilon$ наступні моделі: іменник + іменник + іменник + іменник $(N+N+N+N-26,04 \%$, наприклад: rescue combat air patrol); прикметник + іменник + іменник + іменник $(A+N+N+N-27,87 \%$, наприклад: regional response coordination center). При розгляді п'ятикомпонентих термінів було визначено наступні найбільш типові частиномовні моделі: прикметни + іменник + іменник + іменник + іменник $(A+N+N+N+N-11,36 \%$, наприклад: amphibious bulk liquid transfer system), прикметник + прикметник + іменник + іменник + іменник $(A+A+N+N+N-9,09 \%$, наприклад: critical joint duty assignment billet), іменник + іменник + іменник + іменник + іменник $(N+N+N+N+N-8,33 \%$, наприклад: coalition forces land component commander). Дещо відмінні результати були отримані після підрахунку типових частиномовних моделей в шестикомпонентних термінах.

Найбільш розповсюджені моделі виглядають наступним чином: прикметник + прикметник + прикметник + сполучник + прикметник + іменник $(A+A+A+C+A+N 13 \%$, наприклад: chemical, biological, radiological, and nuclear hazard), прикметник + іменник + іменник + сполучник + іменник +іменник $(A+N+N+C+N+N-8 \%$, наприклад: special operations command and control element). Як ми можемо помітити принциповою відмінністю у цій категорії багатокомпонентних термінів є присутність сполучника у складі частиномовної моделі.

За результатами кількісного аналізу багатокомпонентні терміни складають переважну більшість від загальної кількості термінів. Серед багатокомпонентних термінів було визначено найбільшу категорію термінів, якою $\epsilon$ двокомпонентні терміни. Проте незважаючи на домінацію у за цим критерієм, цю категорію не можна назвати найпродуктивнішою 3 точки зору різноманітності частиномовних моделей. Також було проаналізовано найбільш продуктивні та середньопродуктивні частиномовні моделі. Найбільш продуктивною категорією багатокомпонентних термінів за кількістю частиномовних моделей виявились чотирьох компонентні терміни. У дослідженні було виявлено 52 відмінні частиномовні моделі. Окремо також було 
відзначено, що різноманітність частиномовних моделей зростає відповідно до кількості компонентів в терміні. Тенденція полягає в тому, що збільшення різноманітності частиномовних моделей зростає у всіх категоріях. Результати цього дослідження перегукуються 3 дослідженнями інших науковців та підтверджують попередні наукові розвідки. Наукова новизна цієї публікації полягає саме в аналізі частиномовних моделей у співвідношенні до їх структурних характеристик, оскільки в переважній більшості інших аналізів на цю тему порівняння проводиться на основі інших критеріїв. Також необхідно відзначити, що актуальність цього дослідження спричинена відсутністю досліджень саме в аспекті військових терміносистем. Аналіз частиномовних моделей також підтвердив твердження, яке фігурувало у попередніх дослідженнях, а саме те, що іменник $є$ однією 3 найпоширеніших частин мови в будь-якій професійній термінології. Результати цієї публікації у подальшому можуть використовуватись для більш детального аналізу частиномовних компонентів англомовних військових термінів та їх відношення 3 іншими критеріями термінів, наприклад їх приналежність до певних груп термінів: інтрагалузевих, екстрагалузевих та загальнонаукових.

\section{Література:}

1. Гринев С. В. Введение в терминоведение. Москва, 1993. 310 с.

2. Даниленко В.П. О терминологическом словообразовании. Вопросы языкознания. 1973. № 4. С. 76-85.

3. Разбєгіна Н. В. Аналітичні номінації термінів міжнародного права. Наукові записки Національного університету «Острозька академія». Серія «Філологічна». 2015. Вип. 58. С. 346-349.

4. Скороходько Е. Ф. Термін у науковому тексті( до створення терміноцентричної теорії наукового дискурсу): монографія. Київ, 2006. $99 \mathrm{c}$.

5. Сліпецька В.Д. Англомовна термінологія штучного інтелекту в контексті інших терміносистем (досвід лінгвостатистичного аналізу): дис. канд. філол. наук: 10.02.04. Київ, 2008. 347 с. 